\title{
Tax-budget Deficit Relationships: Fiscalists' Platform for Deficit Financing Policy
}

\author{
Samuel O. Okafor ${ }^{1}$, Olisaemeka D. Maduka ${ }^{1}$, Ann N. Ike ${ }^{2}$, Benedict I. Uzoechina ${ }^{3}$, Celestine I. Ohachosim ${ }^{1}$ \\ ${ }^{1}$ Department of Economics, Nnamdi Azikiwe University, Awka, Anambra State, Nigeria \\ ${ }^{2}$ Department of Banking and Finance, Federal Polytechnic, Oko, Anambra State, Nigeria \\ ${ }^{3}$ Department of Economics, Renaissance University, Ugbawka, Enugu, Enugu State, Nigeria \\ Correspondence: Samuel O. Okafor, Department of Economics, Nnamdi Azikiwe University, P.M.B. 5025, Awka, \\ Anambra State, Nigeria.
}

Received: April 23, 2017

doi:10.11114/bms.v3i3.2531
Accepted: June 7, 2017

Online Published: July 11, 2017

URL: https://doi.org/10.11114/bms.v3i3.2531

\begin{abstract}
With heavy debt burden on developing economies accompanied by their low credit worthiness rating, developing economies often resort to taxes for financing development projects. Raising tax rates and expanding tax bases have become frequent government activities in developing economies. Without dynamic deficit financing policy which takes into cognizance the conflicting arithmetic and economic effect of Laffer curve analysis, financing budget deficit through taxation has remained largely unsuccessful. Perhaps, what was required is to constitute latent factors operating along Laffer curve into major theoretical construct of a deficit financing policy. Therefore, study focused on identifying latent factors influencing the inter-relationship among budget deficit finance, taxes, human capital and macroeconomic indicators. Study spanned across 1970-2015. Data were sourced from Central Bank of Nigeria, National Bureau of Statistics and World Development Indicators. Data were analyzed using exploratory factor analysis. Results indicate that: (1) Tax contributed significantly to budget deficit financing (2)Tax spending and disposable personal income were latent factors influencing the effectiveness of deficit financing (3) Tax spending activated government revenue to contribute significantly to budget deficit reduction (4) Disposable personal income boosted GDP to cause reduction in budget deficit. It was concluded that, with the taxonomy of highly significant factor correlates of tax spending and disposable personal income, a viable deficit financing policy was devised with component tax, budgetary, pricing, credit and macroeconomic policies. It was recommended, inter alia, that developing economies should activate their current deficit financing policies by adapting them to their tax spend and macroeconomic policies.
\end{abstract}

Keywords: deficit financing policy, tax policy, factor analytic approach, fiscalist platform, tax spending, disposable personal income

\section{Introduction}

Deficit financing is a veritable fiscal policy instrument for achieving sustainable economic growth in developing countries. The use of budget deficit financing for enhancing economic growth started at the end of World Wars I and II necessitated by the ensuing depression, crash in international oil price and international financial crises (Gaber, 2010). According to Gaber, the three ways of budget deficit financing include tax, borrowing and monetization. Along this line, Paiko (2012) asserted that when there is a budget deficit, government finances budget deficit through borrowing from commercial banks or from non banking public and through the issue of short term bonds and monetary instrument. On his part, Keynes in the 'General Theory' had recommended deficit financing as a fiscal policy instrument for stimulating aggregate demand via multiplier effect for the attainment of full employment in the capitalist economy. However, excessive and prolong deficit financing through creation of high-powered money may prove counterproductive in the attainment of macroeconomic stability and subsequently impede the desired level of investment in the economy. It is in this context that the post-Keynesian economists' views are considered as alternative approach to debt financing of development projects. Lin and Doemeland (2012) had cast aspersion, based on the views of several economists and politicians, on the efficacy of Keynesian stimulus. According to them, "a global infrastructure initiative, which scales up bottleneck-releasing infrastructure projects in advanced as well as developing countries, would go beyond the traditional Keynesian stimulus along several key dimensions" 
Deficit financing has become an important feature of Nigeria's budgetary process. Frequent use of deficit financing in Nigeria is borne out of the desire to maintain fiscal discipline and macroeconomic stability and also to ensure the attainment of sustainable economic growth. The profile of deficit financing in Nigeria's budgetary process has been presented in Table 1.

Table1. Nigeria's Budget Estimates 2006-2015 (\# Billion)

\begin{tabular}{llll}
\hline YEAR & GRV & GEX & GBD \\
2006 & 5965.102 & 6066.500 & -101.397 \\
2007 & 5715.600 & 5832.837 & -117.237 \\
2008 & 7866.590 & 7913.969 & -47.378 \\
2009 & 4844.592 & 5654.601 & -810.008 \\
2010 & 7303.672 & 8409.113 & -110.544 \\
2011 & 3410.100 & 3541.900 & -131.800 \\
2012 & 3572.520 & 3845.100 & -272.500 \\
2013 & 3905.380 & 4046.800 & -141.420 \\
2014 & 3672.030 & 3983.00 & -310.950 \\
2015 & 2859.020 & 3469.160 & -610.140 \\
\hline
\end{tabular}

Source: Okafor, Maduka, Ike and Uzoechina (2017)

Table 1 shows that estimated expenditures were in excess of estimated revenues thereby yielding budget deficits between 2006 and 2015.

Nigeria has relied heavily on domestic and foreign borrowings as an instrument of deficit financing. But the impact of deficit financing on the Nigerian economy is negative (Paiko, 2012). This is because, as Paiko observed, domestic and foreign borrowing often leads to crowding out of private investment, inflation as well as future debt crises. The structural adjustment programme (SAP) of 1986 was implemented with the London and Paris Club loan of US\$35.994 billion guaranteed by the International Monetary Fund (IMF). Federal government's (FG) inability to repay the London and Paris Club loan had imposed heavy debt burden on Nigeria and eroded the credit-worthiness rating of the country. The debt relief from the London and Paris Club loan granted during the Obasanjo administration in 2005 was a sad experience which cast a serious aspersion on the continued application of foreign borrowing as an instrument of deficit financing in Nigeria. No wonder, the Nigerian National Assembly was reluctant in approving the US\$30 billion loan application by the Buhari administration in 2016.

It is in this context that the FG proposed tax policy could be construed as a preferred choice of deficit financing through taxation over budget deficit financing through public borrowing and monetization. Certainly, the FG proposed tax policy which aims at eliminating multiple taxes and improving tax administration in Nigeria is considered both dynamic and progressive. According to Tanzi and Zee (2000), tax policy should play a sensitive role in emerging markets through raising sufficient revenues to finance expenditures without recourse to excessive public borrowing and raising sufficient revenues in the economy without reducing productive activities. The economic consequences of raising taxes for financing budget deficit have been properly articulated in the views of Laffer (2004) that raising taxes penalizes participation in tax activities. Perhaps, all that is required is to subject the proposed tax policy to the operation of Laffer curve theory in order to enhance its effectiveness for financing budget deficit. Ostensibly, the FG proposed tax policy with two pronged strategies of eliminating multiple taxes and raising existing tax rates might be considered effective for generating sufficient government revenues to finance development projects and achieve sustainable growth. However, it is still doubtful that raising existing tax rates and expanding tax bases to generate revenue for budget deficit financing would not impact negatively on productive activities in the economy. Thus, the problem of this study was the nonexistence of properly articulated deficit financing policies in most developing countries due to their limited access to international financial market and their limited tax administration capabilities. To solve this problem, the study carried out a detailed analysis of interrelationships among budget deficit finance, taxes, human capital and macroeconomic indicators in order to isolate factors concealed in these interrelationships which would serve as multipliers and possibly, could be constituted into major active instruments of a dynamic deficit financing policy.

\section{Review of Related Literature}

\subsection{Theoretical Review}

Keynesian Theory of Budget Deficits

The Keynesian theory differs from neoclassical theory in two ways: (1) It is based on the assumption that some factors of production are unemployed (2) There is a large number of myopic and financially constrained individuals. It can be deduced from the second assumption that aggregate consumption is susceptible to changes in disposable income (Bernheim, 1989). In its simplistic form, Keynesian model posited that increasing budget deficit leads to expansion in 
output. However, under standard IS-LM curve analysis, expansion in output not accompanied by increase in money supply and corresponding reduction in interest rate leads generally to disincentive to invest, contraction in output and inevitably a distortion of Keynesian multiplier effect. The major weakness of this theory is the inherent tendency of increase in budget deficit to lead to crowding out effect. Many traditional Keynesian argue that deficits need not crowd out private investment (Eisner, 1986). Despite its weakness, this theory was considered relevant to the present study which sought to identify potent factors influencing the relationship between budget deficit and tax revenues.

\section{Laffer Curve Theory}

Laffer curve theory expresses the relationship between tax rates and tax revenues. According to Laffer (2004), changes in tax rates have two effects-arithmetic effect and economic effect. The arithmetic effect is that if tax rates are lowered, then the tax revenues will be lowered in the same proportion as the reduction in tax rate. The converse is also true. The economic effect is that lowering of tax rate has positive effect on work, output and employment thereby expanding the tax base for increasing these activities. Raising tax rates has the opposite economic effect by penalizing participation in the taxed activities. Laffer curve theory has been severally criticized by scholars and policy-makers as "trickle down" and "voodoo economics"- phrases coined up by President George H.W. Bush to discredit it. Despite these criticisms, many authors including Moore (2014) had argued that his theory has actually held up pretty well these past 40years. The relevance of Laffer curve theory for the present study derives from the conscientious efforts put in this paper to identify potent factors influencing the contributions of tax to budget deficit for a possible integration as active instruments of a dynamic policy of deficit financing through taxation.

\section{New Structural Economic Theory}

This theory is associated with the name of Justin Yifu Lin. According to Lin(2011), from the new structural economics viewpoint, fiscal policy affects developed and developing countries in different ways due to differentials in opportunities which exist in the counter-cyclical expenditure to induce high rate of productive investment. He opined that lack of physical infrastructures generally constitutes a hindrance to growth in developing countries requiring that governments play an active role in the provision of basic infrastructures in order to foster economic development. It is in this context that recessions are considered to be conducive to investment in infrastructure for quick economic recovering. Lin had adduced three major reasons to support this theoretical viewpoint. Firstly, infrastructural investments during recession boost short-term demand and promote long-term growth. Secondly, the cost of investment during recession is lower than in normal times. Thirdly, it provides the policy makers a certain degree of flexibility and viable options to exit from Ricardian equivalence trap (Lin, 2009). Certainly, the emphasis of the new structural economic theorists on the development strategy of infrastructural investment during recession raises some contending issues bordering on the resourcefulness of most highly indebted poor countries among developing economies to invest in infrastructures. Undoubtedly, revenues for such infrastructural investment in developing countries most of which are caught up in poverty trap can only come from tax sources. Thus, the new structural theory has reinforced Laffer curve theory as a vibrant theoretical base for the present study. Besides, it has provided a prior justification for this study aimed at isolating factors concealed in tax-budget deficit nexus which would serve as active instruments of a viable deficit financing policy.

The preferred choice of Laffer curve theory over Keynesian theory of budget deficit and new structural economic theory as theoretical base for the present study was made because Laffer curve analysis attempted to provide answers to the numerous questions which the FG's proposed tax policy is likely to pose. Raising indirect taxes in Nigeria in the recent time could possibly have consequences which might be explicated in terms of the arithmetic and economic effects of Laffer curve theory. Besides, the selection of relevant variables and their ordering in the model used in this study have been made in strict conformity with the expectations of Laffer curve theory.

\subsection{Empirical Review}

Tanzi and Zee (2000) embarked on a study to address emerging tax policy issues being faced by developing countries. It focused on macroeconomic perspective of level and composition of tax revenue and also on microeconomic perspective of certain design aspects of selected major taxes. Study reviewed the role of tax incentives in developing countries. Study identified one of the acute policy challenges faced by developing countries as limited tax administration capabilities and their high dependence on foreign trade taxes. Study recommended the provision of stable and transparent legal and regulatory frameworks as well as adequate supporting institutions in order to achieve sustained investment promotion. The strength of this study derives from its immense contribution to the present study which found its recommendation a starting point for a confirmatory factor analysis.

Thapa (2005) studied the implication of deficit financing for effective management. Study spanned across 1987-2004. Study was essentially a qualitative research adopting a theoretical approach to analyzing the data. Finding indicates that high indebtedness for financing excessive deficits erode the resource base of the country. Study concluded that deficit 
financing via public debt leads developing countries to comfortable liquidity profile which is implicated in effective debt management. Finding has policy implication for governments in LDCs to augment their revenues through borrowing for the purpose of financing their budget deficits to achieve sustainable growth. The design of this study as a qualitative research has provided a much desired relief from the frequent use of econometric technique commonly found in economic literature. This study yielded results which were found useful for comparing with the results of the present study.

Upender (2008) investigated the tax buoyancy in India's tax system. Study covered the period, 1950-2005. Data were analyzed using ADF, Phillips Parron and multiple regression techniques. Results suggest that: (1) Gross tax was moderately elastic (2) Average propensity to tax increased as GDP increased during the pre-tax period (3) There was a downward shift in the degree of tax buoyancy during the post tax reform period (4) Average propensity to tax decreased steadily during the post tax reform period. Findings have policy implication for governments in LDCs to test the validity of Laffer curve theory in their situations before any consideration to alter tax rates and tax bases. A drawback of the study is the discernible ambiguity in the results of the study. Nevertheless, the study yielded evidences which were used to support the analytical framework of the present study.

Padda and Akram (2009) investigated the impact of tax policies on economic growth in South-Asian economies. Study covered the period, 1973-2008. Data were analyzed using ADF and multiple regression technique. Findings indicate that: (1) Tax policy in South-Asian economies had transitory impact on their economic growth (2) A higher tax reduced permanently the level of output but had no permanent effects on the output growth rate. Policy implication of findings is the need for governments to adopt a cautious approach towards raising taxes to finance their budget deficits. A drawback of the study is the under reporting of research proceeding. However, the study has created an insight which guided the conduct and advancement of the present study.

OECD (2010) was motivated by the recent financial and economic crises to review the existing tax policies of member countries with a view to activating their public finances without necessarily jeopardizing growth. OECD investigated how tax structures could best be designed to support economic growth. Study identified tax reform strategies that would enable policy makers to initiate effective tax reforms. OECD report recommended shifting part of the tax burden from income to consumption and residential property and also the assignment of greater role for environmental taxes and fees. Policy implication of findings is the need for government to impose taxes on luxury items and property as well as levy environmental fees as catalyst for growth. The applicability of the recommendations of this report could be constrained by the discernible lack of details on methods and procedure of investigation. However, OECD investigation provided a desired stimulus for successful implementation of the present project.

Gaber (2010) examined the economic implications of deficit finance. He adopted qualitative approach towards analyzing the major growth effects of deficit financing including multiplier effect, crowding out effect and twin deficit effect. Results suggest that the implication of multiplier effect for growth is to increase aggregate demand and national income while the implication of crowding out effect for growth is to crowd out private sector from the capital market under increased demand for loan-able funds. Finding has policy implication for government to be cautious while deciding on fiscal deficit option for enhancing economic growth. Strength of the study derives from its detailed analysis of various growth effects of fiscal deficit. Its relevance to the present study lies in its usefulness in the elaborate discussion of the results of this study.

Ferry and Eckersley (2011) embarked on a comprehensive review of budgeting and governing for deficit reduction in the UK public sector. Study sought to explain how the comprehensive spending review was used to provide a framework for a long term planning of annual budget in UK, with special reference to England. Study was essentially qualitative in nature. Study revealed that growth which was relatively more certain and facilitated incremental budgeting in the past is now uncertain due to reduction in public spending. Study concluded that public spending reductions would slow down the rate of growth and job creation or even trigger another recession. Policy implication of finding is the need for governments to prepare such budget estimates which would avert situations where public revenues are low while welfare and interest payments remain high for too long to exacerbate current deficit problem. The strength of this study lies in its insight into the nature of relationship among public spending, public revenue, growth, interest payments and welfare. It was considered relevant to the present study which sought to identify factors influencing the interrelationship among budget deficit finance, taxes, human capital and macroeconomic indicators.

Paiko (2012) examined the implication of deficit financing for stimulating investment in Nigeria's private sector. Study covered the period, 1990-2007. Study employed OLS technique for the analysis of data. Result suggests that there was inverse relationship between deficit financing and investment in Nigeria's private sector. Study recommended that federal government should devise a fiscal policy which would be conducive for high rate of productive investment in the country's private sector. Weakness of this study is that multiple regression was applied to analyze data from a 
sample with size as small as 18 . Howbeit, the study was found useful for comparing with the results of the present study.

Okafor and Uzoechina (2013) carried out a study to identify the tax factor in Nigeria's fiscal policy for reducing budget deficit and enhancing growth. Study employed factor analysis for the analysis of data. Findings indicate that: (1) Potent tax factor in Nigeria's fiscal policy was corporate tax (2) Tax policy was reinforced by monetary policy for effective fiscal deficit reduction (3) Fiscal policy was characterized by inconsistencies in the preferred choice between countercyclical and compensatory approaches (4) Deficit financing via external debt was inflationary. Policy implication of findings is the need for government to infuse corporate tax as the main component of its tax policy to strengthen fiscal policy. A drawback of this study is the non inclusion of the study period. Howbeit, the study provided a much-needed stimulus for conducting and advancing the present study.

Ndedzu, Macheka, Ithiel and Zivengwa (2013) studied the productivity of Zimbabwe's tax system. Study covered the period, 1975-2008. Data were analyzed using multiple regression technique. Results indicate that: (1) Taxes in Zimbabwe, excepting custom duties, were not productive (2) Discretionary measures were effective for raising additional tax revenue. Policy implication of findings to the government is the need to improve on tax administration, reduced tax evasion and cut down the number of tax exemptions. A limitation of this study is the use of multiple regression for analyzing the data which were not tested for stationarity. However, the study was considered useful to the extent it yielded results which served as a prior expectations of the present study.

Prante and Hodge (2013) studied tax-spend policies in US. Bureau of Economic Analysis data and micro-simulation model yielded the data for this study. Data were analyzed using Cost-Benefit analysis. Study revealed that tax spending policies led to distribution of income in US. Policy implication of finding is the need for US lawmakers to remove equity as an issue in tax reform by matching any loss in progressivity on the tax side with an equal increase in progressivity on the spending side. A limitation of this study is the hotch-potch style of research reporting. Notwithstanding, the study has yielded result which supported the results of the present study.

Gale and Samwick (2014) studied the effect of income tax changes on economic growth. Study adopted historical design which relied extensively on simulation analysis of data that spanned across 1870-2011. Study revealed, among others, that base broadening measures could eliminate the effect of tax rate cuts on budget deficits, but at the same time, they reduce the impact on labour supply, saving and investment and thus reduce the direct impact on growth. Policy implication of finding is that no decisions to broaden tax bases or finance budget deficit through tax should be divested of consideration of implications of Laffer curve effect. The study was considered relevant to the present study which sought to develop a policy of tax financing of budget deficit.

Samuel and Tyokoso (2014) investigated the impact of taxation on revenue generation in selected Nigerian states. Study covered the period, 2002-2011. Sample comprised of 300 members of federal and state Inland Revenue Services and 100 tax payers. Study employed descriptive and inferential statistics for the analysis of data. Results suggest that: (1) Taxation contributed significantly to revenue generation (2) Taxation contributed significantly to GDP (3) Tax evasion and tax avoidance had significant impact on revenue generation. Findings have policy implication for the government to improve the quality of tax administration in Nigeria so as to minimize tax evasion and tax avoidance. A drawback of this study is that the recommendations were not based on the findings of the study. Howbeit, the study was an eye-opener to the purposeful pursuit of the present study.

Nwaeke and Korgbeelo (2016) investigated the impact of deficit financing on the Nigerian economy. Study spanned across 1981-2013. Data were analyzed using multiple regression technique. Findings indicate that: (1) Deficit financing via external debt had non-significant impact on growth, while deficit financing with domestic debt impacted positively on growth (2) Deficit financing did not contribute significantly to inflation (3) Deficit financing through domestic sources contributed significantly to unemployment. Policy implication of findings is the need for federal government to make a preferred choice of domestic sources over external debt for financing its budget deficits. A major limitation of this study is its contempt for the use of deficit financing as a veritable fiscal instrument. Notwithstanding, the study provided a much needed direction to the conduct of the present study.

Das (2016) studied the impact of the composition of expenditures of Indian sub-national governments on their degree of indebtedness. Study covered the period, 1980-2013. Data from 17 non-special category states were used for the study. Study employed panel analysis technique for the analysis of data. Results indicate that: (1) Aside from budget structure, specific factors affecting fiscal performance in the states impacted significantly on government borrowing (2) Government borrowing was more responsive to revenue expenditure than capital outlay (3) Debt financing impacted positively on economic growth. Policy implication of findings is the need for the union government to develop debt financing policy with the specific factors as its policy instruments. A drawback of this study is its weak analytical framework which could not support a strong statement on the relationship among government borrowing, public 
expenditure and economic growth. Howbeit, the study was considered relevant to the present study as it yielded evidences for validating this study.

\subsection{Summary of Review}

Theoretical literature review has established unanimity in agreement among the proponents and exponents of the reviewed theories that deficit financing through taxation requires that a balance be maintained between growth-maximizing and revenue-maximizing tax rates in order to enhance economic growth through deficit financing. The determination of the appropriate tax rate to yield sufficient revenue for financing budget deficit without compromising growth creates the need for the informed choice of Laffer curve theory over Keynesian theory and the new structural economic theory for the formulation of deficit financing policy.

Review of empirical literature has revealed that even though taxation and deficit financing have aroused and sustained the interests of researchers for several years, still a proper linkage between the two has not been achieved in any of the studies in a conscientious effort to develop a policy of deficit financing via taxation. This could have been due to conflicting findings of the various studies, an offspring of methodological issues which did not allow for consistencies in approach, objective and reasoning to facilitate such linkages. It is this gap which was sought to be filled by the present study which aimed at isolating potent factors in the relationship between tax components and budget deficit to be constituted into active instruments of a dynamic policy of tax financing of budget deficit.

\section{Method and Procedure}

\subsection{Data}

The study was designed essentially as a case study. Nigeria was considered as a typical example of developing economies. The study covered the period, 1970-2015. Data were sourced from Central Bank of Nigeria, National Bureau of Statistics and World Development Indicators. The selection of variables and their inclusion in the analysis were in conformity with the requirements of Ricardian, Keynesian, Laffer curve and new structural economic theories.

\subsection{Empirical Model}

As stated earlier, the study aimed at developing a policy of deficit financing through taxation with potent factors in tax-budget deficit nexus to be constituted into major active instruments of the policy. The model used in this study was adopted with modification from Paiko (2012), and Okafor, Maduka, Ike and Uzoechina (2017). This has been presented below:

\section{$\mathrm{BDF}=\mathrm{F}(\mathrm{TGR}, \mathrm{CIT}, \mathrm{CED}$, PPT, VAT, REE, RHE, CEE, CHE, PIV, PCE, GDP)}

Where BDF is budget deficit finance; TGR is total government revenue; CIT is company income tax; CED is custom and exercise duties; PPT is petroleum profit tax; VAT is value-added tax; REE is recurrent education expenditure; RHE is recurrent health expenditure; CEE is capital education expenditure; CHE is capital health expenditure; PIV is private investment; PCE is private consumption expenditure and GDP is gross domestic product.

\subsection{Factor Model Specification}

This study used common factor model. The a prior justification for the preferred used of common factor model was the application of Paiko's (2012) model which expresses a linear functional relationship among Yt, S1, S2, S3 and S4; where $\mathrm{Yt}$ is P1 (private investment), $\mathrm{S} 1$ is GM (government expenditure public sector borrowing from the commercial banking system), $\mathrm{S} 2$ is $\mathrm{D}_{\mathrm{B}}$ (budget deficit); $\mathrm{S} 3$ is $\mathrm{XD}$ (external debt stock); $\mathrm{S} 4$ is $\mathrm{R}_{\mathrm{T}}$ (interest rate). Okafor et al. (2017) had also expressed a functional relationship among BDF, TGR, CIT, CED, PPT, VAT, REE, RHE, CEE, CHE, PIV, PCE, GDP and EMP where BDF is budget deficit finance; TGR is total government revenue; CIT is company income tax; CED is custom and exercise duties; PPT is petroleum profit tax; VAT is value-added tax; REE is recurrent education expenditure; CEE is capital education expenditure; CHE is capital health expenditure; PIV is private investment; PCE is private consumption expenditure; GDP is gross domestic product and EMP is employment. The present study has also adopted a model which expresses a functional relationship among BDF, TGR, CIT, CED, PPT, VAT, REE, RHE, CEE, CHE, PIV, PCE and GDP. Common factor model is appropriate when the variables are a linear function of a set of latent variables (Tucker, Koopman \& Linn, 1969; Ford, MacCallum \& Tait, 1986). The underlying assumption of common factor model is that the variance is usually divided into common and unique components with the unique variance being further divided into specific and random error variance (Rummel, 1970).

There are 13 variables- BDF (CRN), TGR, CIT, CED, PPT, VAT, REE, RHE, CEE, CHE, PIV, PCE and GDP. Factor analysis model requires that the variables included in the analysis should be linearly related to each other. The factor model used for this study was developed by Cornish (2007). This model has been expressed algebraically in the form:

$$
\mathrm{Xi}=\alpha \mathrm{i} 1 \mathrm{~F} 1+\alpha \mathrm{i} 2 \mathrm{~F} 2+\ldots+\alpha \mathrm{imFm}+\mathrm{ei}
$$


Suppose there are $\mathrm{p}$ variables $\mathrm{X} 1, \mathrm{X} 2, \ldots \mathrm{Xp}$ measured on a sample of $\mathrm{n}$ subjects, variable $\mathrm{i}$ is a linear combination of $\mathrm{m}$ factors $\mathrm{F} 1, \mathrm{~F} 2, \ldots, \mathrm{Fm}$ and $\mathrm{m}<\mathrm{p}$, where $\alpha$ is are the factor loadings for variable $\mathrm{i}$ and ei is that part of variable $\mathrm{Xi}$ that cannot be explained by the factors.

Since there are 13 variables, the rule of thumb requires that only one-third of the total number of variables could be extracted as factors. Therefore, the factor analysis model has been expressed in the form:

$$
\mathrm{BDF}=\alpha \mathrm{i} 1 \mathrm{~F} 1+\alpha \mathrm{i} 2 \mathrm{~F} 2+\alpha \mathrm{i} 3 \mathrm{~F} 3+\alpha \mathrm{i} 4 \mathrm{~F} 4+\mathrm{ei}
$$

Where $\alpha \mathrm{i} 1$ is the factor loading of Factor 1

ai2 is the factor loading of Factor 2

$\alpha \mathrm{i} 3$ is the factor loading of Factor 3

ai4 is the factor loading of Factor 4

ei is the part of criterion variable BDF that cannot be explained by that factor.

\subsection{Validation Technique}

To determine the suitability of factor analysis for the present study, Kaiser-Meyer-Olkin (KMO) statistic and Bartlett's test of sphericity (Chi-Square) were computed. KMO statistic was employed for ascertaining whether or not the factors were comprised of sufficient numbers of variables while Chi-Square $\left(\chi^{2}\right)$ was used to ascertain whether or not the variables were sufficiently correlated. KMO value should be greater than 0.7 in order to confirm that the factors contain sufficient numbers of variables. Also, $\chi^{2}$ value should be significant at 0.05 confidence interval to infer that the variables were sufficiently correlated (Cornish, 2007).

Table 2. Results of KMO and Bartlett's Test

\begin{tabular}{ll}
\hline Kaiser-Meyer-Olkin Measure of Sampling Adequacy & .714 \\
Bartlett's Test of Sphericity Approx. Chi-Square & 1632.187 \\
df & 78 \\
sig & .000 \\
\hline
\end{tabular}

As can be seen in Table 2 , computed KMO statistic $=0.714$ while $\chi^{2}$ value $=1632.187(\mathrm{p} \leq 0.000)$. Now, since the computed KMO statistic is greater than the criterion $\mathrm{KMO}$, the factors were considered to contain sufficient numbers of variables. Also, $\chi^{2}$ value of $1632.187(\mathrm{p} \leq 0.000)$ was considered to be significant at 0.05 confidence interval indicating thereby that the variables included in the model were sufficiently correlated. Thus, the use of factor analysis in the study stands justified.

\subsection{Eigenvalues for Determination of Number of Factors}

Cornish (2007) had developed a simple procedure for determining the number of factors to be extracted. He suggested that to determine the number of factors to be extracted, say $\mathrm{m}$, the number of eigenvalues should be divided by 1 to obtain $\mathrm{m}$. The eigenvalues have been presented in Table 3 .

Table 3. Eigenvalues for Determination of Number of Factors

\begin{tabular}{lllllll}
\hline & \multicolumn{3}{c}{ Initial Eigenvalues } & \multicolumn{3}{c}{ Extraction Sums of Squared Loadings } \\
\hline Component & Total & $\%$ of Variance & Cumulative \% & Total & $\%$ of Variance & Cumulative \% \\
\hline 1 & 9.864 & 75.881 & 75.881 & 9.864 & 75.881 & 75.881 \\
2 & 1.628 & 12.521 & 88.402 & 1.628 & 12.521 & 88.402 \\
3 & .644 & 4.957 & 93.358 & & & \\
4 & .441 & 3.390 & 96.749 & & & \\
5 & .237 & 1.826 & 98.574 & & & \\
6 & .097 & .745 & 99.319 & & & \\
7 & .048 & .369 & 99.688 & & & \\
8 & .024 & .184 & 99.873 & & & \\
9 & .008 & .063 & 99.936 & & & \\
10 & .004 & .030 & 99.966 & & & \\
11 & .003 & .027 & 99.992 & & & \\
12 & .001 & .006 & 99.999 & & & \\
13 & .000 & .001 & 100.000 & & & \\
\end{tabular}


Table 3 shows that the number of eigenvalues is two. Following Cornish's procedure, two divided by one yields two which is the number of factors to be extracted.

\subsection{Evaluation Criteria}

The study employed exploratory factor analysis (EFA) for the present study. The main focus of EFA was to constitute the factor structure of tax-budget deficit relationship in Nigeria. Principal axes method was used for the factorization of the inter-correlation matrix. The conservative rule of thumb requires that no decision should be made on the significance of unrotated loadings, e.g., as obtained from centroid method or the method of principal axes (Nunnally, 1967). Thus, following this principle, Varimax rotation of the matrix was carried out.

By rotating the factors slightly in a clockwise direction, the strength of the relationship between the factors and the variables clustered near each other was increased (Pophan, 1967; Kline, 1994). Rotation improves the meaningfulness, reliability and reproducibility of factors (Weiss, 1976; Ford et al, 1986). Results of EFA were interpreted on the basis of new values of factor loadings obtained through the use of 'Orthogonal Rotation' formula expressed in the form of X1= $\mathrm{X} \operatorname{Cos} \theta+\mathrm{Y} \sin \theta$. Factor loadings which were equal to or greater than \pm 0.4 were considered to be significant. Ford et al. (1986) had suggested the inclusion of factor loading $\geq 0.4$. Factor loadings of the criterion variable were provided for all factors disregarding the level of significance in order to ascertain whether or not the factors represented correlates of BDF. The process of factor extraction was discontinued when the number of factors equalled two which is the result obtained when the eigenvalues, i.e., two was divided by one (Cornish, 2007). Extracting too many factors may present undesirable error variance but extracting too few factors might leave out valuable common variance (Yong \& Pearce, 2013).

\section{Results}

The results of data analysis have been presented in tables and interpreted under the following subheadings:

-Inter-correlation matrix

-Tax-budget deficit finance relationship in Nigeria

-Factor structure of tax-budget deficit relationship

-Varimax (rotated) factor structure of tax-budget deficit relationship

-Factors influencing the relationship between tax and budget deficit finance

-Categorization of factor correlates into policy instrument

\subsection{Inter-correlation Matrix}

Inter-correlations among budget deficit finance (CRN) and 12 predictor variables have been presented in Table 4 .

Table 4. Correlation Matrix (13X13) Among BDF (CRN) and Predictor Variables

\begin{tabular}{lllllllllllllll}
\hline S.No. & $\begin{array}{l}\text { Variable } \\
\text { Codes }\end{array}$ & 1 & 2 & 3 & 4 & 5 & 6 & 7 & 8 & 9 & 10 & 11 & 12 & 13 \\
\hline 1 & BDF & $\mathrm{X}$ & & & & & & & & & & & \\
2 & TGR & -.818 & $\mathrm{X}$ & & & & & & & & & & \\
3 & CIT & -.869 & .953 & $\mathrm{X}$ & & & & & & & & & \\
4 & CED & -.809 & .932 & .952 & $\mathrm{X}$ & & & & & & & & \\
5 & PPT & -.788 & .946 & .965 & .955 & $\mathrm{X}$ & & & & & & & \\
6 & VAT & -.931 & .946 & .966 & .901 & .905 & $\mathrm{X}$ & & & & & & \\
7 & REE & -.900 & .955 & .930 & .880 & .876 & .981 & $\mathrm{X}$ & & & & & \\
8 & RHE & -.923 & .929 & .917 & .861 & .861 & .973 & .979 & $\mathrm{X}$ & & & & \\
9 & CEE & -.599 & .516 & .654 & .610 & .604 & .595 & .517 & .526 & $\mathrm{X}$ & & & \\
10 & CHE & -.877 & .975 & .957 & .910 & .911 & .978 & .981 & .977 & .573 & $\mathrm{X}$ & & & \\
11 & PIV & -.666 & .520 & .581 & .494 & .507 & .702 & .687 & .687 & .263 & .619 & $\mathrm{X}$ & & \\
12 & PCE & -.673 & .516 & .581 & .495 & .507 & .701 & .686 & .690 & .262 & .618 & .999 & $\mathrm{X}$ & \\
13 & GDP & -.539 & .237 & .355 & .305 & .312 & .434 & .382 & .511 & .161 & .373 & .634 & .660 & $\mathrm{X}$ \\
\hline
\end{tabular}

Table 4 shows that all the inter-correlations are of zero order. Also, as can be seen in the table, all inter-correlations are greater than 0.30 . Therefore, the variables included in the model were considered to be sufficiently inter-correlated to warrant the application of factor analysis. Tabachnick and Fidell (2007) had recommended that correlation, r, must be 0.30 or greater since anything lower would suggest a really weak relationship between the variables. 


\subsection{Tax -Budget Deficit Finance Relationship in Nigeria}

Correlation coefficients among CIT, CED, PPT, VAT and BDF after partially out the effects of other predictor variables-TGR, REE, RHE,CEE, CHE, PIV, PCE and GDP have been presented in Table 5 to facilitate discussion of tax-budget deficit relationship. Coefficient of determination $\left(\mathrm{r}^{2}\right)$ was also computed in order to estimate the percentage contribution of tax revenue to budget deficit in Nigeria.

Table 5. Partial Correlation and Coefficient of Determination Between Tax Components and Budget Deficits

\begin{tabular}{llrrlll}
\hline \multirow{2}{*}{ S.No } & Variable codes & \multicolumn{2}{c}{ BDF } & Per cent contribution & Probability & Decision \\
\cline { 2 - 7 } & Predictor & $\mathrm{r}$ & $\mathrm{r}^{2}$ & & & \\
\hline 1 & CIT & -0.869 & -0.755 & -75.00 & 0.000 & Significant \\
2 & CED & -0.809 & -0.654 & -65.40 & 0.000 & Significant \\
3 & PPT & -0.788 & -0.621 & -62.10 & 0.000 & Significant \\
4 & VAT & -0.931 & -0.867 & -86.70 & 0.000 & Significant \\
\hline
\end{tabular}

NB: Minus signs on $\mathrm{r}$ and $\mathrm{r}^{2}$ indicate direction only

Table 5 shows that: $\mathrm{r}_{\text {cit } / \mathrm{bdf}}=-0.869(\mathrm{p} \leq 0.000)$ yielded $\mathrm{r}_{\text {cit } / \mathrm{bdf}}^{2}=-0.755$ representing -75.50 per cent. $\underline{\mathrm{r}}_{\text {ced } / \mathrm{bdf}}=-0.809$ $(\mathrm{p} \leq 0.000)$ yielded $\mathrm{r}_{\text {ced } / \mathrm{bdf}}^{2}=-0.654$ representing -65.40 per cent. $\underline{\underline{p}}_{\mathrm{ptt}} / \mathrm{bdf}=-0.788(\mathrm{p} \leq 0.000)$ yielded $\mathrm{r}_{\mathrm{ppt} / \mathrm{bdf}}^{2}=-0.621$ representing -62.10 per cent. $\underline{\mathrm{r}}_{\mathrm{vat} / \mathrm{bdf}}=-0.931(\mathrm{p} \leq 0.000)$ yielded $\mathrm{r}_{\text {vat } / \mathrm{bdf}}^{2}=-0.867$ representing -86.70 per cent. These results indicate that: (1) There were significant inverse relationships among CIT, CED, PPT, VAT and BDF (2) CIT, CED, PPT and VAT contributed -75.50 per cent, -65.40 per cent, -62.10 per cent and -86.70 per cent respectively to BDF. In other words, the impact of CIT, CED, PPT and VAT on BDF was to reduce it to the extent of 75.50 per cent, 65.40 per cent, 62.10 per cent and 86.70 per cent respectively.

\subsection{Factor Structure of Tax-Budget Deficit Relationship}

Factor structure of taxes and budget deficit finance relationship has been presented in Tables 6 and 7 to facilitate the extraction of factors lying concealed in the inter-relationships among the criterion variable and the predictor variables.

Table 6. Principal Axes (Original) Factor Structure of Tax Components-Budget Deficits Relationships (N=46)

\begin{tabular}{|l|l|l|l|l|}
\hline S.No. & $\begin{array}{l}\text { Variable } \\
\text { Codes }\end{array}$ & Factor 1 & Factor 2 & $\mathrm{h}^{2}$ \\
\hline 1 & BDF & -.928 & -.064 & .866 \\
2 & TGR & .938 & -.263 & .949 \\
3 & CIT & .967 & -.195 & .973 \\
4 & CED & .918 & -.267 & .915 \\
5 & PPT & .921 & -.258 & .915 \\
6 & VAT & .993 & -.035 & .986 \\
7 & REE & .973 & -.043 & .949 \\
8 & RHE & .975 & .025 & .950 \\
9 & CEE & .611 & -.334 & .484 \\
10 & CHE & .974 & -.129 & .966 \\
11 & PIV & .725 & .619 & .908 \\
12 & PCE & .726 & .631 & .925 \\
13 & GDP & .489 & .683 & .706 \\
\hline
\end{tabular}

NB: Factor loadings are rounded to three decimal places

Table 6 shows the original principal components factor matrix. The last column reveals the communalities $\left(\mathrm{h}^{2}\right)$. On the whole EFA led to the extraction of two factors.

\subsection{Varimax (rotated) Factor Structure of Tax-Budget Deficit Relationship}

Principle axes (original) factor matrix was rotated orthogonally to yield new values for the factor loadings. The results have been presented in Table 7. 
Table 7. Varimax (Rotated) Factor Matrix for Tax Components-Budget Deficits Relationships (N=46)

\begin{tabular}{|c|c|c|c|c|c|}
\hline S.No. & $\begin{array}{l}\text { Variable } \\
\text { Codes }\end{array}$ & Factor 1 & Factor 2 & $h^{2}$ & $\mathrm{U}^{2}=\left(1-\mathrm{h}^{2}\right)$ \\
\hline 1 & BDF & -.777 & -.512 & .866 & .134 \\
\hline 2 & TGR & .946 & .231 & .949 & .051 \\
\hline 3 & CIT & .938 & .305 & .973 & .027 \\
\hline 4 & CED & .931 & .218 & .915 & .085 \\
\hline 5 & PPT & .929 & .228 & .915 & .085 \\
\hline 6 & VAT & .882 & .457 & .986 & .014 \\
\hline 7 & REE & .869 & .441 & .949 & .051 \\
\hline 8 & RHE & .837 & .500 & .950 & .050 \\
\hline 9 & CEE & .696 & .009 & .484 & .516 \\
\hline 10 & CHE & .912 & .366 & .966 & .034 \\
\hline 11 & PIV & .327 & .895 & .908 & .092 \\
\hline 12 & $\mathrm{PCE}$ & .323 & .906 & .925 & .075 \\
\hline 13 & GDP & .091 & .835 & .706 & .294 \\
\hline \multirow{3}{*}{\multicolumn{2}{|c|}{$\begin{array}{l}\text { Sum of squares } \\
\text { Percentage of total variance } \\
\text { Percentage of common variance }\end{array}$}} & 7.877 & 3.615 & & \\
\hline & & 60.593 & 27.809 & & \\
\hline & & 60.593 & 27.809 & & \\
\hline
\end{tabular}

Table 7 shows the Varimax factor loadings along with communalities and uniqueness of variables. The total variance of any variable comprises of common variance $\left(\mathrm{h}^{2}\right)$ as well as specific and error variance. Since it is usually difficult to separate specific variance and error variance, both are conveniently combined and denoted by unique variance $\left(\mathrm{U}^{2}\right)$. This has been inserted in the last column of this table. At the end of each column of the factor, the eigenvalues, i.e., percentages of total variance and common variance contributed by the factor were entered.

\subsection{Factors Influencing the Relationship between Tax and Budget Deficit Finance}

To identify Factors 1 and 2 which have crystallized from data analysis, Table 6 was split further into two sub-tables-Tables 7.1 and 7.2 to facilitate discussion on the significant factor loading of each of the rotated factors.

\subsubsection{Factor 1}

It has already been explained earlier, that the Varimax rotation of original factor matrix involving the determinants of tax and budget deficit was carried out. The resulting Varimax rotated version has been presented in descending order in Table 7.1.

Table 7.1. Varimax Factor 1

\begin{tabular}{|l|l|l|l|}
\hline S.No. & Description of variables & Codes & Factor loading \\
\hline 2 & Total government revenue & TGR & .946 \\
3 & Company income tax & CIT & .938 \\
4 & Custom and exercise duties & CED & .931 \\
5 & Petroleum profit tax & PPT & .929 \\
10 & Capital health expenditure & CHE & .912 \\
6 & Value-added tax & VAT & .882 \\
7 & Recurrent education expenditure & REE & .869 \\
8 & Recurrent health expenditure & RHE & .837 \\
9 & Capital education expenditure & CEE & .696 \\
1 & Budget deficit financing & BDF(CRN) & -.777 \\
\hline
\end{tabular}

Table 7.1 shows that the criterion variable BDF was clustered with the dimensions of TGR, CIT, CED, PPT, CHE, VAT, REE, RHE and CEE in descending order. This factor represented mainly different dimensions of tax revenues in conjunction with budget deficit on the one hand and different dimension of government spending in conjunction with $\mathrm{BDF}$ on the other. These results indicate that certain common elements were shared by sub-variables of government revenues and BDF on the one hand and elements of sub-variables of government spending with BDF on the other so as to account for a common factor. In the light of significant loadings on the variables of government revenue and government spending, this factor could be identified as tax spending. The constellations of dimensions of government 
revenue and the dimensions of public spending with BDF paved the way for considering the various dimensions of tax spending as plausible correlates of BDF.

The extent of common factor variance accounted for by tax spending was found to be 60.59 per cent which is also 60.59 per cent of the total variance in BDF contributed by the two factors. Positive significant loading on TGR (0.946) and negative significant loading on BDF (-0.777) imply that tax spending had positive valence for TGR and negative valence for BDF. In other words, tax spending activated TGR to cause a reduction in BDF in Nigeria.

\subsubsection{Factor 2}

Table 7.2 summarizes significant factor loadings of rotated Varimax Factor 2 in their descending order.

Table 7.2. Varimax Factor 2

\begin{tabular}{|l|l|l|l|}
\hline S.No & Description of variables & Codes & Factor loading \\
\hline 12 & Private consumption expenditure & PCE & .906 \\
11 & Private investment & PIV & .895 \\
13 & Gross domestic product & GDP & .835 \\
8 & Recurrent health expenditure & RHE & .500 \\
6 & Value-added tax & VAT & .457 \\
7 & Recurrent education expenditure & REE & .441 \\
1 & Budget deficit financing & BDF(CRN) & -.512 \\
\hline
\end{tabular}

Highly significant loadings on Factor 2 in their descending order were on PCE (0.906), PIV (0.895) and GDP (0.835). Thus, all the macroeconomic variables contributed significant factor variance to Factor 2. Three other variables which contributed significant factor variance to Factor 2 include the following: RHE (0.500), VAT (0.457) and REE (0.441). This factor has clearly brought together income and expenditure dimensions, which in absence of VAT conform to Keynesian income-expenditure approach. Since GDP (economy's output) symbolized as Y can be disaggregated into consumption and investment (aggregate demand), Factor 2 is certainly one of the five series of national income account other than GDP. The highest positive factor loading on PCE and positive significant loadings on RHE and REE, though moderate, reduced to near zero the chances that Factor 2 could be either personal income or per capita income. This is because per capita income and personal income do not respond instantaneously to changes in PCE, RHE and REE. Only disposable personal income is closely connected to consumption expenditures which play an important part in macroeconomic theories (Bronfenbrenner, Sichel\& Gardner, 1982). Since PCE, RHE, and REE fall in the domain of consumption expenditures, Factor 2 cannot be anything other than disposable personal income. And so it is termed. This is confirmed by positive significant factor loading on VAT as increase in disposable personal income leads to increase in VAT revenues.

Percentage of common variance contributed by disposable personal income was 27.81 which is 27.81 per cent of the total variance contributed by the two factors to the variance in budget deficit. Positive significant loading on GDP $(0.835)$ and negative significant loading on BDF (-0.512) imply that disposable personal income had positive valence for GDP and negative valence for BDF. Put differently, disposable personal income boosted GDP to cause a reduction in BDF.

\subsection{Categorization of Factor Correlates into Policy Instruments}

To formulate a dynamic deficit financing policy, factor correlates have been categorized into active policy instruments in this section. This has been presented in Table 8 . 
Table 8. Classification of Factor Correlates into Tax Policy Instruments

\begin{tabular}{|l|l|l|l|}
\hline S.No. & $\begin{array}{l}\text { Factor } \\
\text { correlates }\end{array}$ & Policy instrument & Corresponding policy \\
\hline 1 & TGR & Revenue generation & Tax policy \\
2 & CIT & Revenue generation & Tax policy \\
3 & CED & Revenue generation & Tax policy \\
4 & PPT & Revenue generation & Tax plicy \\
5 & CHE & Budget & Budgetary policy \\
6 & PCE & Distribution & Pricing policy \\
7 & PIV & Stock exchange & Credit policy \\
8 & VAT & Revenue generation & Tax policy \\
9 & REE & Budget & Budgetary policy \\
10 & RHE & Budget & Budgetary policy \\
11 & GDP & Aggregate supply & Macroeconomic policy \\
\hline
\end{tabular}

Table 8 shows clearly the steps involved in the formulation of a viable deficit financing policy. The table shows that the factor correlates of BDF, namely, TGR, CIT, CED, PPT, CHE, PCE, PIV, VAT, REE, RHE and GDP have been transformed into their equivalent policy instruments of revenue generation, budget, distribution, stock exchange, revenue generation, budget and aggregate supply respectively. These results indicate that, with the constitution of the policy instruments into their corresponding policies, the resulting viable deficit financing policy is comprised of five components including tax policy, budgetary policy, pricing policy, credit policy and macroeconomic policy.

\subsection{Diagrammatic Representation of Factors and Modal Summary}

The two factors which were isolated from EFA have been presented diagrammatically in Figures 1 and 2.

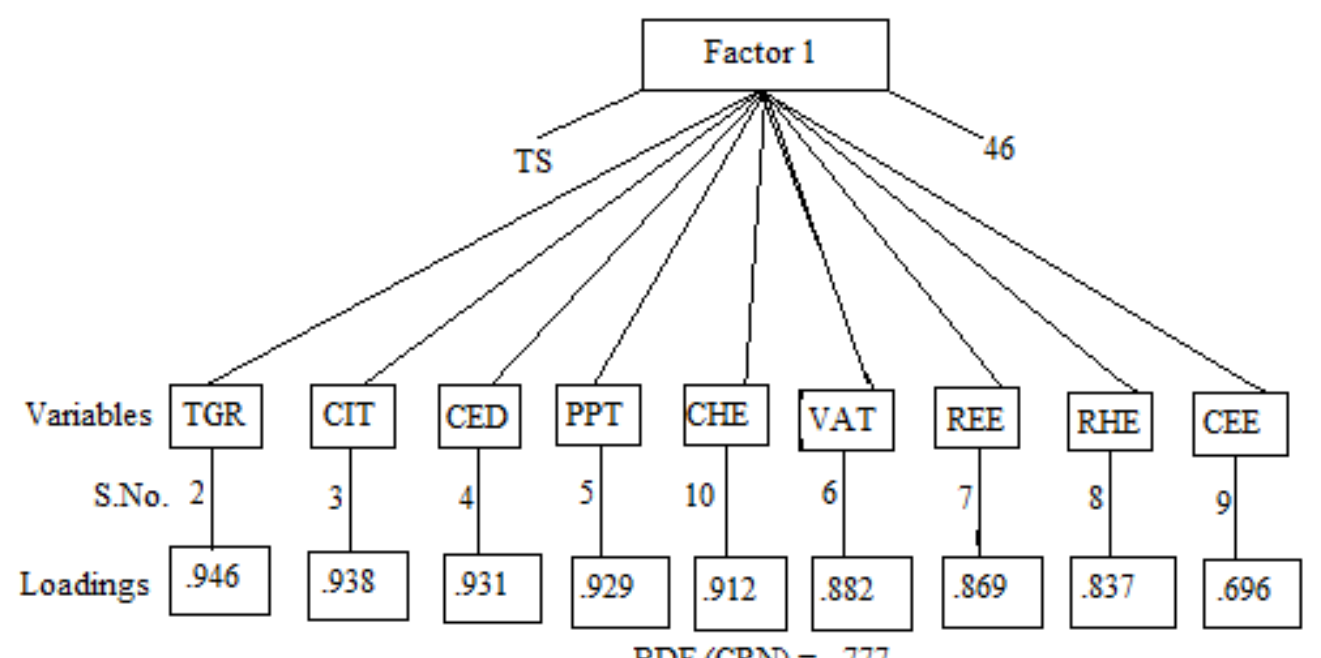

Figure 1. Factor 1: Tax spending 


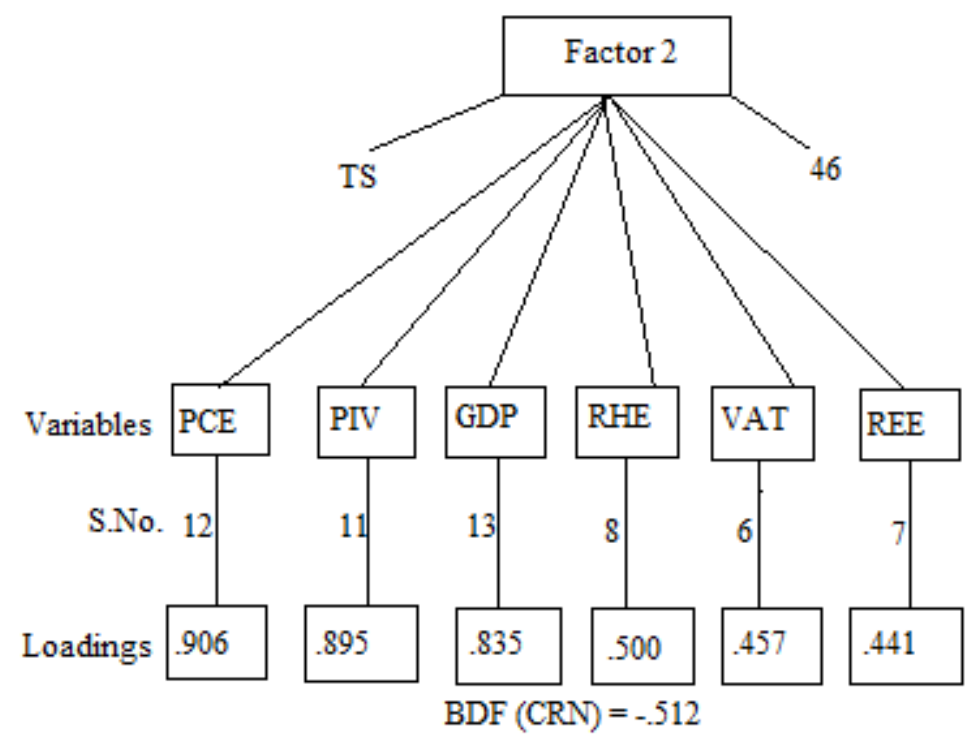

Figure 2. Factor 2: Disposable Personal Income

The results of data analysis using EFA have been summarized in the form:

$\mathrm{BDF}=-0.777$ Tax spending-0.512 Disposable personal income

4.8 Summary of Major Findings

Major findings which have emerged from the study include the following:

1. Tax contributed significantly to budget deficit financing.

2. Tax spending and disposable personal income were two potent factors influencing the effectiveness of deficit financing.

3. Tax spending activated total government revenue to contribute to budget deficit reduction.

4. Disposable personal income boosted GDP to cause a reduction in budget deficit.

5. Tax, budgetary, pricing, credit and macroeconomic policies are integral components of viable deficit financing policy.

\section{Discussion of Findings and Conclusion}

\subsection{Discussion of Findings}

The sizeable contribution of tax to government revenue in Nigeria is the natural outcome of the size and structure of the Nigerian economy. It is only a normal dividend accruable to a large market economy dependent on import and export of crude oil. Under these circumstances, tax buoyancy can only be assumed. It is reasonable to expect that revenues from taxes in a country of over 170 million people would constitute a large chunk. It is even more reasonable to surmise that revenues from corporate tax from the world's seventh largest exporter of crude oil would represent a sizeable proportion of total government revenue. And for a wholly import-dependent economy like Nigeria, the yield from custom and exercise duties would be unimaginably high. It is in the context of the above-stated facts that this finding conforms to the a priori expectations of this study. This finding is in agreement with the finding reported by Okafor and Uzoechina (2013) and Samuel and Tyokoso (2014) but contradicts the finding reported by Ndedzu et al(2013) that taxes in Zimbabwe, excepting custom duties were not productive.

The emergence of tax spending and disposable personal income as potent factors influencing the effectiveness of deficit financing has almost resolved the hitherto unsettled issues on productivity of the Nigerian tax system and its potentials to yield sufficient revenues for financing budget deficits. Tax spending and disposable personal income are twin products of cumulative effect of interaction among various tax components and macroeconomic variables. There is nothing unorthodox and unscientific about the appearance of tax spending and disposable personal income. Tax spending lies concealed in the operations involving the formulation of budgetary policy of public sector. It is an extraction from the relationship between total government revenue from corporate tax and public spending patterns. Its importance in this analysis derives from its allocation function, i.e., channelling indirect tax revenues to capital and recurrent health and education expenditures. On its own part disposable personal income is an extraction from the relationship between aggregate demand and aggregate supply, a product of Keynesian income-expenditure approach. Its importance in the present analysis derives from its distribution function, i.e., distributing the output of the economy 
between investment and saving to ensure the attainment of macroeconomic stability. This finding is supported by Eisner's (1986) view that deficits need not crowd out private investment and also Bernheim's (1989) deduction that aggregate consumption is susceptible to changes in disposable income.

The capacity of tax spending to activate total government revenue to contribute significantly to budget deficit reduction is a natural consequence of the strong association between indirect tax revenue and government spending. As stated earlier, tax spending is a product of interaction between indirect tax revenue and public spending. Being depicted in the budgetary policy of the public sector as income and expenditure components of the budget, tax spending is armed with the allocation powers of a budget to channel government revenues to the preferred spending needs of the economy. In this particular case, under purview, by allocating total government revenue between capital and recurrent expenditures in health and education sectors, tax spending improves the efficiency of deficit financing. This finding confirms Prante and Hodges's (2013) finding that tax and spending policies redistribute income in US. It is also in concurrence with Gale and Samwick's (2014) finding which indicates that if tax cuts are not financed by immediate spending cuts they could lead to an increase in budget deficit.

The inherent powers of disposable personal income to boost gross domestic product to contribute significantly to budget deficit reduction are a simple derivative of effects of interaction among personal income, taxes, savings and investment. This is because an increase in disposable personal income implies a reduction in tax rate and corresponding increase in saving and consumption. It is in this sense that the Laffer curve analysis of arithmetic and economic effect of reduction in tax rates comes into effect. Whether the tax reduction leads to higher savings or higher consumption would depend on marginal propensity to consume (MPC) and marginal propensity to save (MPS). One thing that stands out clearly is that reduction in tax rate has both arithmetic and economic effects. The arithmetic effect of reduction in tax rate is a decrease in tax revenue while its economic effect is an increase in the output of the economy (in this case, GDP) due to incentive to participation in taxed activities. Now, the disposable personal income, acting through the economic effect of tax reduction, boosted MPS which distributed GDP in such a way that larger proportion was committed to saving or capital for financing budget deficit.

The dynamic deficit financing policy which has evolved in this study is comprised of diverse component policies including, tax, budgetary, pricing, credit and macroeconomic policies. These component policies fall in the domain of public finance and macroeconomic theories. Therefore, it is expected that equipped with the tools and methods of public sector policies, these component policies can inject into a market economy the efficiency of public finance in allocation of resources, distribution of income and stabilization of macroeconomic indicators. The effectiveness of the deficit financing policy depends to a large extent on the degree of accuracy of prediction of satisficing disposable personal income that will strike a balance between revenue-maximizing and growth-maximizing tax rates. Similar theoretical perspectives of deficit financing policy were held by Musgrave and Musgrave (1989).

\subsection{Conclusion}

The final outcome of this study is that a dynamic policy of deficit financing via taxation is comprised of the following components: Tax policy, budgetary policy, pricing policy, credit policy and macroeconomic policy. This deficit financing policy rests on the fiscalist platform which is reverted on twin products of tax-budget deficit interactive mode namely, tax spending and disposable personal income. Thus, tax spending and disposable personal income are the two major constructs which have provided a theoretical base for this policy. They work separately to effect a reduction in budget deficit. Through a proper implementation of the component policies, these constructs operate conjointly, thereby, reinforcing each other to enhance the efficiency of deficit financing policy. Instructively, this study conveys clearly that deficit financing does not begin with revenues generation or end with creating deficits in the budget. Obviously, what is required is a review of the existing component policies or a formulation of new component policies with the potentials to induce tax spending and disposable personal income to enhance deficit financing. The importance of this study, however, derives from the facile integration of the component policies into an active instrument for financing budget deficit. Indeed, the weakness of this study has metamorphosed into its strength which is dearth of an identical elaborate deficit financing policy for comparison. However, the weakness of the study soon gets subsumed in its immense value as the aroma of Laffer pessimism begins to fade, yielding place to 'Laffer optimism' as indirect tax revenues are spent on budget deficits on health and education and direct tax revenues are expended on infrastructural deficits. In fact, the true worth of the new deficit financing policy would be determined by the ease and success with which the recommendations in the next section are implemented.

\section{Policy Prescriptions}

Based on the findings of the study and the accompanying discussion, the researchers have made the following policy prescriptions:

1. Positive significant contribution of tax to total government revenue creates the need for developing economies to 
consider, as a matter of priority, tax as viable sources of revenue for financing budget deficit.

2. The direct action of tax spending in boosting government revenue for effective deficit financing imposes on the developing economies the need to channel functional finance to capital and recurrent expenditures on health and education.

3. With the disposable personal income acting as an activator of GDP to enhance deficit financing, the next viable option for developing economies is to settle for a tax rate which would yield a satisficing disposable personal income capable of striking a balance between revenue- maximizing and growth-maximizing tax rates.

4. The new deficit financing policy comprised of component policies including tax policy, budgetary policy, pricing policy, credit policy and macroeconomic policy requires direct actions of government in developing economies to review the existing component policies in their countries with a view to adapting them to their current tax-spend and macroeconomic policies.

\section{Acknowledgements}

We express our profound gratitude to Mrs Ifeoma Josephine Okafor, wife of the principal researcher for her immense contribution to this article. To God, be the glory.

\section{References}

Bernheim, B. D. (1989). A neoclassical perspective on budget deficits. The Journal of Economic Perspective, 3(2), 55-73. https://doi.org/10.1257/jep.3.2.55

Bronfenbrenner, M., Sichel, W., \& Gardner, W. (1982). Macroeconomics. Houghton: Mifflin.

Cornish, R. (2007). Statistics: Factor analysis. Mathematics learning support centre 1-3.

Das, P. (2016). Debt dynamics, fiscal deficit and stability in government borrowing in India: A dynamic panel analysis. ADBI Working Paper No 557. https://doi.org/10.2139/ssrn.2746297

Eisner, R. (1986). How real is the federal deficit? New York: The Free Press, 240, 14. https://www.auburn.edu/ garriro/r8eisner.htm

Ferry, L., \& Eckersley, P. (2011). Budgeting and governing for deficit reduction in the UK public sector: Act one the comprehensive spending review. Journal of Finance and Management in Public Services, 10(1), 14-23.

Ford, J. K., MacCallum, R. C., \& Tait, M. (1986). The application of exploratory factor analysis in applied psychology: A critical review and analysis. Personnel psychology, 8(2), 291-314. https://doi.org/10.1111/j.1744-6570.1986.tb00583.x

Gaber, S. (2010). Economic implications from deficit finance. BERG Working Paper No. 69, 1-13.

Gale, W. G., \& Samwick, A. A. (2014). Effects of income tax changes on economic growth. Brookings Economic Studies, 1-15. https://doi.org/10.2139/ssrn.2494468

Kline, P. (1994). An easy guide to factor analysis. London: Routledge.

Laffer, A. B. (2004). The laffer curve: Past, present and future. Executive Summary Backgrounder, No. 1765, 1-16. www.heritage.org/research/reports/2004/06/

Lin, J. Y. (2009). Beyond Keynesianism. Harvard International Review, 31(2), 14-17.

Lin, J. Y. (2011). New structural economics: A framework for rethinking development. The World Bank Research Observer, 26(2), 193-221. https://doi.org/10.1093/wbro/lkr007

Lin, J. Y., \& Doemeland, D. (2012). Beyond Keynesianism: Global infrastructure investments in times of crisis. World Bank Policy Research Working Paper, 5940, 1-40. https://doi.org/10.1142/s1793993312500159

Moore, S. (2014). The Laffer curve turns 40: The legacy of a controversial idea. https://www.washingtonpost.com/opinions/the-laffer-curve-at-40-still-looks-good/2014/12/26/4cded164-8

Musgrave, R. A., \& Musgrave, P. B. (1989). Public finance in theory and practice ( $5^{\text {th }}$ edition). New York: McGraw Hill.

Ndedzu, D., Macheka, A., Ithiel, M. M., \& Zivengwa, T. (2013). Revenue productivity of Zimbabwe's tax system. Asian Journal of Social Sciences \& Humanities, 2(4), 144-156.

Nunnally, J. C. (1967). Psychometric theory. New York: McGraw Hill.

Nwaeke, G. C., \& Korgbeelo, C. (2016). Budget deficit financing and the Nigerian economy. European Journal of Business and Management, 8(22), 206-214. 
OECD (2010). Tax policy reform and economic growth, OECD tax policy studies, No. 20, OECD Publishing. https://doi.org/10.1787/9789264091085-en

Okafor, S. O., \& Uzoechina, B. I. (2013). Tax factor in Nigeria's fiscal policy for reducing budget deficit and enhancing growth. Journal of Economic Studies, 10(1), 32-41.

Okafor, S. O., Maduka, O. D., Ike, A. N., \& Uzoechina, B. I. (2017). Tax-financing of budget deficits in LDCs: Re-validation of Laffer curve theory. Applied Economics and Finance, 4(3), 89-101. https://doi.org/10.11114/aef.v4i3.2297

Padda, I. U. H., \& Akram, N. (2009). The impact of tax policies on economic growth: Evidence from South-Asian economies. The Pakistan Development Review, 48(4), 961-971.

Paiko, I. I. (2012). Deficit financing and its implication on private sector investment: The Nigerian experience. Arabian Journal of Business and Management, 1(10), 45-62. https://doi.org/10.12816/0002187

Popham, W. J. (1967). Educational Statistics. New York: Harper \& Row Publishers.

Prante, G., \& Hodge, S. (2013). The distribution of tax and spending policies is the United States. Tax Foundation Special Report N0. 211. https://taxfoundation.org/distribution-tax-spending-policies-united-states/pdf

Rummel, R. J. (1970). Applied Factor Analysis. Evanston. IL: Northwestern University Press.

Samuel, S. E., \& Tyokoso, G. (2014). Taxation and revenue generation: An empirical investigation of selected states in Nigeria. Journal of Poverty, Investment and Development, 4, 102-114.

Tabachnick, B.G., \& Fidell, L.S. (2007).Using multivariate statistics (5th ed.).Boston, MA: Allyn \& Bacon.

Tanzi, V., \& Zee, H. H. (2000). Tax policy for emerging markets: Developing countries. National Tax Journal, 53(2), 299-322. https://doi.org/10.17310/ntj.2000.2.07

Thapa, G. B. (2005). Deficit financing: Implications and management. Economic Review, 16-26.

Tucker, L. R., Koopman, R. F., \& Linn, R. L. (1969). Evaluation of factor analytic research by means of correlation matrices. Psychometrika, 34(4), 421-459. https://doi.org/10.1007/BF02290601

Upender, M. (2008). Degree of tax buoyancy in India: An empirical study. International Journal of Applied Econometrics and Quantitative Studies, 5(59-70).

Weiss, D. (1976). Multivariate Procedures. In: M.E. Dunnette (Ed.) Handbook of industrial/organizational psychology. Chicago, IL: Rand McNally.

Yong, A. G., \& Pearce, S. A. (2013). Beginner's guide to factor analysis: Focusing on exploratory factor analysis. Tutorials in Quantitative Methods for Psychology, 9(2), 79-94. https://doi.org/10.20982/tqmp.09.2.p079

\section{Copyrights}

Copyright for this article is retained by the author(s), with first publication rights granted to the journal.

This is an open-access article distributed under the terms and conditions of the Creative Commons Attribution license which permits unrestricted use, distribution, and reproduction in any medium, provided the original work is properly cited. 